OPEN ACCESS

Edited by:

Wei Jiang,

Guangxi University, China

Reviewed by:

Arjen Tilstra,

University of Bremen, Germany

Luis Montilla,

Anton Dohrn Zoological Station, Italy

*Correspondence:

Valentine Meunier valentine.meunier@ird.fr

Specialty section: This article was submitted to

Coral Reef Research,

a section of the journal

Frontiers in Marine Science

Received: 08 April 2021

Accepted: 05 July 2021

Published: 28 July 2021

Citation:

Meunier V, Bonnet S, Benavides M, Ravache A, Grosso O, Lambert $C$ and Houlbrèque $F$ (2021)

Diazotroph-Derived Nitrogen Assimilation Strategies Differ by

Scleractinian Coral Species.

Front. Mar. Sci. 8:692248.

doi: 10.3389/fmars.2021.692248

\section{Diazotroph-Derived Nitrogen Assimilation Strategies Differ by Scleractinian Coral Species}

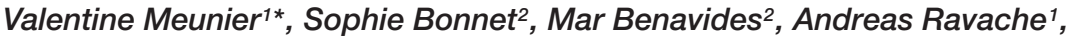 \\ Olivier Grosso ${ }^{2}$, Christophe Lambert ${ }^{3}$ and Fanny Houlbrèque ${ }^{1}$
}

\footnotetext{
${ }^{1}$ Centre IRD Nouméa, UMR ENTROPIE (IRD, Université de La Réunion, CNRS, Université de La Nouvelle-Calédonie, Ifremer), Nouméa, New Caledonia, ${ }^{2}$ Aix-Marseille Université, Université de Toulon, CNRS, IRD, MIO UM 110, Marseille, France, ${ }^{3}$ Univ Brest, CNRS, IRD, Ifremer, LEMAR, Plouzané, France
}

Reef-building corals generally thrive in nutrient-poor tropical waters, where among other elements, nitrogen $(\mathrm{N})$ availability often limits primary productivity. In addition to their close association with endosymbiotic dinoflagellates of the family Symbiodiniaceae, enabling an effective use and retention of dissolved inorganic nitrogen (DIN), scleractinian corals have developed strategies to acquire new N: (1) They can ingest $\mathrm{N}$-rich sediment particles and preys (from picoplankton to macro-zooplankton) via heterotrophy, including diazotrophs [plankton fixing dinitrogen $\left(\mathrm{N}_{2}\right)$ and releasing part of this nitrogen-Diazotroph-Derived $N(D D N)$-in seawater], a pathway called "heterotrophic nutrition on diazotroph"; (2) Symbiotic diazotrophs located in the coral holobiont have the molecular machinery to fix $N_{2}$, a pathway called "symbiotic $N_{2}$ fixation". Here we used the ${ }^{15} \mathrm{~N}_{2}$ isotopic labeling in a series of incubations to investigate the relative contribution of each of these DDN transfer pathways in three worldwide distributed coral species: Acropora muricata, Galaxea fascicularis, and Pocillopora damicornis. We show that $\mathrm{N}$ provision via "symbiotic $\mathrm{N}_{2}$ fixation" is negligible compared to that obtained via "heterotrophic nutrition on diazotrophs," with DDN assimilation rates about a thousand times lower for $P$. damicornis and $G$. fascicularis, or assimilation rates via "symbiotic $\mathrm{N}_{2}$ fixation" almost nil for $A$. muricata. Through heterotrophic feeding on planktonic diazotrophs, only $G$. fascicularis and $P$. damicornis can successfully obtain $\mathrm{N}$ and fulfill a large part of their $\mathrm{N}$ requirements (DDN asimilation rates: $0.111 \pm 0.056$ and $0.517 \pm 0.070 \mu \mathrm{g} \mathrm{N} \mathrm{cm}{ }^{-2} \mathrm{~h}^{-1}$ in their Symbiodiniaceae, respectively). Whereas this contribution is again negligible for $A$. muricata. They also largely consume the picoplankton that likely benefit from this DDN (Prochlorococcus and Synechococcus cells; respectively, $2.56 \pm 1.5710^{4}$ and $2.70 \pm 1.6610^{4}$ cell $\mathrm{h}^{-1} \mathrm{~cm}^{-2}$ for $\mathrm{G}$. fascicularis; $3.02 \pm 0.1910^{5}$ and $1.14 \pm 0.7910^{4} \mathrm{cell} \mathrm{h}^{-1} \mathrm{~cm}^{-2}$ for $P$. damicornis). The present study confirms the different dependencies of the three tested species regarding heterotrophy, with $P$. damicornis and $G$. fascicularis appearing highly efficient at capturing plankton, while $A$. muricata, considered as mainly autotroph, does not rely on these food resources to meet its $\mathrm{N}$ and energy needs.

Keywords: dinitrogen fixation, DDN assimilation, scleractinian corals, heterotrophy, diazotrophs, picoplankton, New Caledonia 


\section{INTRODUCTION}

Reef-building corals generally thrive in nutrient-poor tropical waters, where among others, nitrogen $(\mathrm{N})$ availability often limits primary production (Howarth, 1988). The highly efficient uptake and recycling of nutrients by corals can explain this paradox (Wild et al., 2004; De Goeij et al., 2013). The close association between the coral animal host and its endosymbiotic dinoflagellate of the family Symbiodiniaceae (LaJeunesse et al., 2018) enables an effective use and retention of nutrients and photosynthates (Muscatine and Porter, 1977). Together with their algal symbionts, corals are associated with a variety of other microorganisms, including viruses, protists, Bacteria, Archaea and fungi, an assemblage termed the coral holobiont (Rohwer et al., 2002; Bourne et al., 2016; van Oppen and Blackall, 2019), which also participate in nutrient supply and recycling (e.g., Rosenberg et al., 2007; Rädecker et al., 2015). Among nutrients, $\mathrm{N}$ is an essential element of many fundamental molecules of living organisms such as nucleic acids (DNA, RNA) and amino acids (proteins, enzymes) and represents an essential basis for all organic activity. Scleractinian corals developed strategies to acquire new N via different pathways (Goreau et al., 1971; Rädecker et al., 2015). First, algal symbionts efficiently take up dissolved inorganic $\mathrm{N}$ (DIN) from surrounding waters and translocate it to coral tissues (Falkowski et al., 1993). Corals can also assimilate dissolved organic $\mathrm{N}$ compounds (DON), such as urea and amino acids from the environment (Muscatine, 1990; Mills et al., 2004). Then, the animal host can ingest N-rich sediment particles and prey via heterotrophy (Houlbreque, 2004; Mills and Sebens, 2004). It is well known that corals feed on mesozooplankton $\left(200 \mu^{-2} \mathrm{~cm}\right.$; which they catch by using their tentacles (Sebens et al., 1996; Ferrier-Pagès et al., 2003; Houlbreque, 2004; Goldberg, 2018), but are also able to trap pico- and nanophytoplankton $(0.2 \mu \mathrm{m}-20 \mu \mathrm{m}$; Houlbreque, 2004; Tremblay et al., 2012; Goldberg, 2018; Sangmanee et al., 2020). Pico- and nanophytoplankton supplies a substantial proportion of the metabolic requirements of most scleractinian corals (Goldberg, 2018; Sangmanee et al., 2020) and represents a continuous available source of food in the reefs (Tremblay et al., 2012). Among plankton, diazotrophs (dinitrogen $\left(\mathrm{N}_{2}\right)$ fixing prokaryotes), are particularly abundant in coral lagoon waters (Turk-Kubo et al., 2015; Messer et al., 2017; Saulia et al., 2020), and heterotrophic nutrition on diazotrophs represent a potential source of $\mathrm{N}$ for corals (Benavides et al., 2016; Meunier et al., 2019). This plankton fixes $\mathrm{N}_{2}$ (Tilstra et al., 2018) transform it into a bioavailable $\mathrm{N}$ form $\left(\mathrm{NH}_{4}{ }^{+}\right)$, and releases part of the recently fixed $\mathrm{N}$ (Diazotroph-Derived N, $\mathrm{DDN}$ ) in seawater, providing available $\mathrm{N}$ for the development of the planktonic food web (Berthelot et al., 2016; Bonnet et al., 2016). Hence, when corals feed on plankton, it can ingest both planktonic diazotrophs, but also plankton that developed on DDN from planktonic diazotrophs (for simplicity, this pathway will be called hereafter "heterotrophic nutrition on diazotrophs"). Finally, symbiotic diazotrophs located in the coral tissue, coral mucus layer and skeleton, have the molecular machinery to fix $\mathrm{N}_{2}$ (Lema et al., 2012; Bednarz et al., 2019) and this pathway has been evidenced as a $\mathrm{N}$ source in several corals species (Santos et al., 2014; Cardini et al., 2015; Tilstra et al., 2019). While recent works have shown that $\mathrm{N}$ acquisition through symbiotic $\mathrm{N}_{2}$ fixation greatly varies in relation to environmental factors, species, but also corals' metabolic status (Rädecker et al., 2015; Bednarz et al., 2017; Benavides et al., 2017; Lesser et al., 2018, 2019), heterotrophic nutrition on diazotrophs has only been demonstrated for one coral species, Stylophora pistillata in Benavides et al. (2016) and Meunier et al. (2019).

The general aim of the present study was to determine how DDN acquisition through symbiotic $\mathrm{N}_{2}$ fixation and heterotrophic nutrition on planktonic diazotrophs vary according to coral species. We used the ${ }^{15} \mathrm{~N}_{2}$ isotopic labeling in a series of incubation experiments to investigate the relative contribution of each DDN transfer pathway in three coral species: Acropora muricata, Galaxea fascicularis and Pocillopora damicornis. Widely distributed around the world, these three species have a different heterotrophic capacity. While the genus Acropora has always been considered largely autotrophic (Conti-Jerpe et al., 2020), Galaxea and Pocillopora are conversely considered with higher heterotrophic capacities (Wijgerde et al., 2011; Toh et al., 2013; Conti-Jerpe et al., 2020; Lyndby et al., 2020).

\section{MATERIALS AND METHODS}

\section{Study Site and Coral Collection}

The study was performed in March 2019 (austral summer). The three coral species tested (Acropora muricata, Galaxea fascicularis, and Pocillopora damicornis) differ in the size of their polyps. A total of 20 apexes $(5 \mathrm{~cm}$ long) of each the coral species were collected between 3 and $5 \mathrm{~m}$ depth at the Crouy reef, New Caledonia $\left(22^{\circ} 15,883^{\prime \prime} \mathrm{S} ; 166^{\circ} 19,658^{\prime \prime} \mathrm{E}\right.$, sampling license issued by the "Province Sud," Government of New Caledonia). Coral fragments were transported in individual zip-lock bags to the Aquarium Des Lagons (Nouméa) in a cooler containing freshly collected seawater. Fragments were allowed to recover prior to the start of the incubations, for $24 \mathrm{~h}$ in a $20 \mathrm{~L}$ aquarium supplied with filtered (porosity $40 \mu \mathrm{m})$ seawater, renewed at a rate of $16.5 \mathrm{l} \mathrm{h}^{-1}$ and mixed using a submersible pump (Aquarium system, microjet MC 320, Mentor, OH, United States). Seawater was maintained under a constant temperature of $26^{\circ} \mathrm{C}$ and coral fragments received a constant irradiance of $120 \pm 10 \mu \mathrm{mol}$ photons $\mathrm{m}^{-2} \cdot \mathrm{s}^{-1}$ (photoperiod $12 \mathrm{~h}: 12 \mathrm{~h}$ light: dark) using two Aquablue plus neon bulbs (blue-white, $15.000 \mathrm{~K}$, Giesemann, Germany).

\section{Measurement of Symbiotic $\mathrm{N}_{2}$ Fixation Rates: ${ }^{15} \mathrm{~N}_{2}$ Incubation Experiments in Filtered Seawater}

We used the ${ }^{15} \mathrm{~N}_{2}$-labeling technique (dissolved ${ }^{15} \mathrm{~N}_{2}$ method, Mohr et al., 2010; Grokopf et al., 2012) as described in Meunier et al. (2019), to quantify symbiotic $\mathrm{N}_{2}$ fixation and the potential transfer of DDN to the Symbiodiniaceae fraction. Ten coral 
fragments from each species were individually incubated for $8 \mathrm{~h}$ (from noon to $8 \mathrm{pm}$, local time) in the dark, into $1 \mathrm{~L}$ glass bottles containing ${ }^{15} \mathrm{~N}_{2}$-enriched $0.2 \mu \mathrm{m}$-filtered seawater continuously stirred with magnets. The ${ }^{15} \mathrm{~N}_{2}$-enriched seawater was prepared as described in Meunier et al. (2019) and its ${ }^{15} \mathrm{~N}$ isotopic enrichment was measured by MIMS (Membrane Inlet Mass Spectrometry; Kana et al., 1994) after the $8 \mathrm{~h}$ of incubation. All beakers were immersed in a water bath to maintain the temperature constant $\left(26.1 \pm 0.3^{\circ} \mathrm{C}\right)$ throughout the experiment.

\section{Measurement of Heterotrophic Nutrition on Diazotrophs Diazotrophy-Feeding Experiments}

In parallel experiments, we quantified the assimilation of DDN via heterotrophic nutrition on diazotrophy in the same three coral species. As described in Meunier et al. (2019), we prelabeled with ${ }^{15} \mathrm{~N}_{2}$, 5 sets of $4.3 \mathrm{~L}$ of seawater containing the natural plankton assemblage (collected at the same site as corals). After $24 \mathrm{~h}$ of incubation with ${ }^{15} \mathrm{~N}_{2}$, this plankton was collected onto $0.4 \mu \mathrm{m}$ polycarbonate filters, and vortexed in a $50 \mathrm{~mL}$ seawater aliquot to resuspend cells. Each concentrated ${ }^{15} \mathrm{~N}_{2}$ enriched natural plankton aliquot was provided to 5 coral fragments per species, each of them being incubated for $8 \mathrm{~h}$, in the dark in separated glass beakers ( 15 beakers in total + controls, see below), continuously stirred with magnets. The natural plankton assemblage was collected at the same site as corals, thus planktonic concentration in the beakers is comparable to natural plankton densities of the sampling site. Three additional control beakers (without corals) were also incubated to quantify pico- and nanoplankton abundance fluctuations in the absence of coral predation (internal grazing, natural cell growth and/or cell death) at the beginning and at the end of the incubations. Incubations were carried out in the dark in order to maximize heterotrophy as, on the reef, coral feeding is exacerbated at night (with polyps more deployed and prey more available) (reviewed by Houlbrèque and Ferrier-Pagès, 2009).

Triplicate aliquots of the ${ }^{15} \mathrm{~N}$-labeled plankton given to corals were also kept for further IRMS analyses to measure the ${ }^{15} \mathrm{~N}_{2}$ enrichment of plankton. Triplicate seawater samples were also collected from each beaker at the beginning and the end of the incubation period for further flow cytometry analyses. Samples were fixed with paraformaldehyde (final concentration of $0.1 \%$ ) for $30 \mathrm{~min}$ at room temperature in the dark, then stored at $-80^{\circ} \mathrm{C}$. Prochlorococcus sp. (0.6 $\mu \mathrm{m})$, Synechococcus sp. (1-2 $\mu \mathrm{m})$, picoeukaryotes and heterotrophic bacteria abundance were analysed with a FACSVerse Flow Cytometer (Becton Dickinson, CA, United States) as described in Meunier et al. (2019), to quantify the respective ingestion rates by each coral species. Heterotrophic bacteria were detected by diluting the medium 10fold with filtered seawater $(0.2 \mu \mathrm{m})$ and staining with $\mathrm{SYBR}^{\circledR}$ Green I (DNA). For Prochlorococcus sp., Synechococcus sp., and picoeukaryotes abundances, quantification was done according to the level of red fluorescence corresponding to Chlorophyll a content, and orange fluorescence representative of pigment contents such as phycoerythrin (especially to discriminate between Synechococcus sp. and other pico- and nanoplankton) and also by size-sorting using $1 \mu \mathrm{m}$ green calibration beads (Marie et al., 1997, 1999).

\section{Sample Preparation}

At the end of the incubation, corals were rinsed six times with filtered seawater to remove cells potentially adhered to the coral surface (Houlbrèque et al., 2003), transferred to ziplock bags and stored at $-20^{\circ} \mathrm{C}$ until analysis. The coral tissue was removed from the skeleton using an air-pick and $20 \mathrm{~mL}$ of $0.45 \mu \mathrm{m}$ filtered seawater and homogenized with a Potter tissue grinder (Rodolfo-Metalpa et al., 2010). Algal symbionts and tissue fractions were separated by centrifugation (Houlbrèque et al., 2003). The pellets containing algal symbionts were dried and ground. Coral tissue solutions were filtered $(15 \mathrm{~mL})$ on pre-combusted GF/F filters under low pressure. The filters and the algal symbionts crushed were encapsulated in tin cups for ${ }^{15} \mathrm{~N}$ analyses using an elemental analyzer coupled to an isotopic ratio mass spectrometer (EA-IRMS, Integra CN, SerConLtd, Cheshire, United Kingdom). The coral tissue fraction was filtered onto GF/F filters that were also analyzed by EA-IRMS. $10 \mathrm{~mL}$ subsample was taken from each homogenate and processed for algal symbionts density and total chlorophyll concentrations (see below). $\mathrm{N}$ assimilation rates into coral tissue and algal symbionts were calculated as described in Benavides et al. (2016).

\section{Ingestion Rates of Pico- and Nanoplankton}

Ingestion rates were assessed by means of the clearance rate, according to previous studies on corals (Houlbrèque et al., 2004; Tremblay et al., 2012), and calculated using the equations of Ribes et al. (1998), which take into account the natural growth and death of the prey during incubations. Ingestion rates were expressed as the number of prey organisms ingested and normalized to the skeletal surface area $\left(\mathrm{cm}^{2}\right)$. Carbon (C) and $\mathrm{N}$ content of ingested preys were estimated using conversion factors from the available literature (summarized in Table 1).

\section{Coral Skeletal Surface Area Normalization}

Picoplankton ingestion rates were standardized per skeletal surface area $\left(\mathrm{cm}^{2}\right)$, estimated using the paraffin wax-dipping method (Stimson and Kinzie, 1991; Naumann et al., 2009).

\section{Statistical Analyses}

All tests were performed using $\mathrm{R}$ version 3.6.1 within RStudio (Version 1.1.456, 2018). Given the small sample size, nonparametric Kruskal-Wallis tests were first used to test for significant differences in algal symbionts densities, total chlorophyll content and picoplankton ingestion rates between species. When significant differences were found, WilcoxonMann-Whitney tests were performed to test for pairwise differences between each species (Table 2). To look for potential differences in DDN assimilation rates by coral species, DDN transfer pathways and compartments, three-way ANOVAs 
TABLE 1 | Carbon and nitrogen cell content (ng cell-1) and related $\mathrm{N}$ assimilation rates $\left(\mu \mathrm{g} \mathrm{cm}^{-2} \mathrm{~h}^{-1}\right.$ ) calculated for Prochlorococcus, Synechococcus using literature conversion factors and the results of the present study (mean $\pm \mathrm{SE}$ ).

\begin{tabular}{|c|c|c|c|}
\hline \multicolumn{4}{|c|}{ DDN transfer pathway: 'symbiotic $\mathrm{N}_{2}$ fixation' } \\
\hline & $C\left(n g C\right.$ cell $\left.{ }^{-1}\right)$ & References & C assimilation ( $\mathrm{ng} \mathrm{C} \mathrm{cm}^{-2} \mathrm{~h}^{-1}$ ) \\
\hline \multicolumn{4}{|l|}{ Galaxea fascicularis } \\
\hline Prochlorococcus sp. & $3.610^{-5(a)}$ & Buitenhuis et al., 2012 & $9.204 \pm 5.65010^{-1}$ \\
\hline Synechococcus sp. & $2.510^{-4(a)}$ & Buitenhuis et al., 2012 & $6.749 \pm 4.153$ \\
\hline \multicolumn{4}{|l|}{ Pocillopora damicornis } \\
\hline Prochlorococcus sp. & $3.610^{-5(a)}$ & Buitenhuis et al., 2012 & $10.859 \pm 0.689$ \\
\hline \multirow[t]{2}{*}{ Synechococcus sp. } & $2.510^{-4(a)}$ & Buitenhuis et al., 2012 & $2.842 \pm 1.974$ \\
\hline & $N\left(\right.$ ng N cell $\left.{ }^{-1}\right)$ & References & $\mathrm{N}$ assimilation ( $\mathrm{ng} \mathrm{C} \mathrm{cm}^{-2} \mathrm{~h}^{-1}$ ) \\
\hline \multicolumn{4}{|l|}{ Galaxea fascicularis } \\
\hline Prochlorococcus sp. & $9.6 \pm 0.910^{-6(b)}$ & Bertilsson et al., 2003 & $0.245 \pm 0.151$ \\
\hline Synechococcus sp. & $3.7910^{-5(c)}$ & Redfield, 1958 & $0.540 \pm 0.332$ \\
\hline \multicolumn{4}{|l|}{ Pocillopora damicornis } \\
\hline Prochlorococcus sp. & $9.6 \pm 0.910^{-6(b)}$ & Bertilsson et al., 2003 & $2.896 \pm 0.184$ \\
\hline Synechococcus sp. & $3.7910^{-5(c)}$ & Redfield, 1958 & $0.227 \pm 0.158$ \\
\hline \multicolumn{4}{|c|}{ DDN transfer pathway: "heterotrophic nutrition on diazotrophs" } \\
\hline & & & DDN assimilation ( $\mathrm{ng} \mathrm{N} \mathrm{cm} \mathrm{cm}^{-2} \mathrm{~h}^{-1}$ ) \\
\hline \multicolumn{4}{|l|}{ Galaxea fascicularis } \\
\hline Tissue: Symbiodiniaceae & & & $1.727 \pm 0.124$ \\
\hline \multicolumn{4}{|l|}{ Pocillopora damicornis } \\
\hline Tissue: Symbiodiniaceae & & & $0.316 \pm 0.021$ \\
\hline \multicolumn{4}{|l|}{ Total $\mathbf{N}\left(\mathrm{ng} \mathrm{N} \mathrm{cm}^{-2} \mathrm{~h}^{-1}\right.$ ) } \\
\hline Galaxea fascicularis & & & 2.512 \\
\hline Pocillopora damicornis & & & 3.439 \\
\hline
\end{tabular}

including interactions were conducted. When the ANOVA determined a significant difference, a Tukey's honest significant difference test (HSD) was used to test for pairwise differences while taking into account the interactions between the different variables (Table 3 ). Given the very large discrepancy in measured values of assimilation rates between the two DDN transfer pathways, a separated two-way ANOVA was used to test the effect of coral species, compartments and DDN assimilation rates on the "symbiotic $\mathrm{N}_{2}$ fixation" pathway values alone (Table 4). The ggplot2 package (Wickham, 2008) was used to create the box plot figures. Throughout the manuscript, values given are expressed as mean \pm SE. Statistical significance was accepted at $P<0.05$.

\section{RESULTS}

\section{Nitrogen Assimilation Through the Activity of Symbiotic Diazotrophs}

In all three coral species incubated with ${ }^{15} \mathrm{~N}_{2}$-enriched seawater, the ${ }^{15} \mathrm{~N}$ enrichment in both compartments (coral tissue and algal symbionts) at the end of the incubation period was higher relative to those at $\mathrm{T}_{0}$. A. muricata presented the lowest ${ }^{15} \mathrm{~N}_{2}$ assimilation rates in both coral tissue and symbionts, with no significant differences between both $\left(2.463 \pm 0.40610^{-5}\right.$ and $1.758 \pm 0.89710^{-5} \mu \mathrm{g} \mathrm{N} \mathrm{cm}{ }^{-2} \mathrm{~h}^{-1}$, respectively, two-way ANOVA, diff $\leq 0.001$, adj. $p$-value $=1$, Table 4$)$. The highest assimilation rates were detected in $P$. damicornis symbionts $\left(3.158 \pm 0.20710^{-4} \mu \mathrm{g} \mathrm{N} \mathrm{cm}^{-2} \mathrm{~h}^{-1}\right)$ compared to those in tissue, for which assimilation rates were below the detection levels. In G. fascicularis, assimilation rates were similar between tissue and symbionts $\left(1.256 \pm 0.57510^{-4}\right.$ and $7.222 \pm 2.63410^{-5} \mu \mathrm{g}$ $\mathrm{N} \mathrm{cm}^{-2} \mathrm{~h}^{-1}$, respectively; two-way ANOVA, diff $\leq 0.001$, adj. $p$-value $=1$, Table 4). DDN assimilation rates were significantly higher in algal symbionts than in the tissue for $P$. damicornis (two-way ANOVA, diff $=+0.0003$, adj. $p$-value $<0.001$, Table 4), and assimilation was greater in $P$. damicornis algal symbionts compared to G. fascicularis and A. muricata algal symbionts

TABLE 2 | Summary of statistical analyses performed with the non-parametric test Mann-Whitney-Wilcoxon test for picoplankton ingestion rates between coral species.

\begin{tabular}{lcc}
\hline Coral species & \multicolumn{2}{c}{ Mann-Whitney-Wilcoxon test } \\
\hline Parameter & W & p-value \\
\hline Ingestion rates_G. fascicularis & & \\
Prochlorococcus: Synechococcus & 11.5 & 0.91 \\
Prochlorococcus: Picoeukayotes & 14.5 & 0.72 \\
Synechococcus: Picoeukayotes & 14.5 & 0.72 \\
Ingestion rates-P. damicornis & & 0.01 \\
Prochlorococcus: Synechococcus & 25 & 0.00 \\
Prochlorococcus: Picoeukayotes & 25 & 0.16 \\
Synechococcus: Picoeukayotes & 19 &
\end{tabular}


TABLE 3 | Results of a three-way factorial ANOVA with coral species, compartments and DDN transfer pathway as explanatory variables on the dependent variable: DDN assimilation rates.

\begin{tabular}{|c|c|c|c|}
\hline Source & Degrees of freedom & $F$-value & $p$-value \\
\hline Coral species & 2 & 26.41 & $<0.001$ \\
\hline DDN transfer pathway & 1 & 112.09 & $<0.001$ \\
\hline Compartments & 1 & 49.97 & $<0.001$ \\
\hline Coral species: DDN transfer pathway & 2 & 52.82 & $<0.001$ \\
\hline Coral species: compartments & 2 & 31.09 & $<0.001$ \\
\hline DDN transfer pathway: compartments & 1 & 93.72 & $<0.001$ \\
\hline Coral species: DDN transfer pathway: compartments & 2 & 62.62 & $<0.001$ \\
\hline
\end{tabular}

(two-way ANOVA, diff $=+0.0002$, ajd. $p$-value $<0.001$ and diff $=+0.0003$, ajd. $p$-value $<0.001$, respectively, Figure 1A).

\section{Nitrogen Assimilation Through the Heterotrophic Nutrition on Diazotrophs}

Very low DDN assimilation rates through heterotrophic nutrition on diazotrophs were measured within $A$. muricata tissue $\left(0.028 \pm 0.008 \mu \mathrm{g} \mathrm{N} \mathrm{cm}{ }^{-2} \mathrm{~h}^{-1}\right)$ and no assimilation was detected in their algal symbionts. There was no significant difference between both compartments in A. muricata (twoway ANOVA, diff $=-0.003$, adj. $p$-value $=0.99$, Table 4). $G$. fascicularis and $P$. damicornis DDN assimilation rates were significantly higher in the symbionts compared to the tissue (two-way ANOVA, diff $=+0.1$, adj. $p$-value $=0.014$ and diff $=+0.5$, adj. $p$-value $<0.001$, respectively, Table 4 ). The highest DDN assimilation rates were detected in the algal symbionts of $P$. damicornis $\left(0.517 \pm 0.070 \mu \mathrm{g} \mathrm{N} \mathrm{cm}^{-2} \mathrm{~h}^{-1}\right)$, for which no assimilation was measured in the tissue. Among the three species tested, assimilation rates in $P$. damicornis algal symbionts were the highest, 4.6-fold and 5-fold greater than in the same compartments for G. fascicularis $(0.111 \pm 0.056 \mu \mathrm{g} \mathrm{N}$ $\mathrm{cm}^{-2} \mathrm{~h}^{-1}$; two-way ANOVA, diff: +0.4 , ajd. $p$-value $<0.001$ ), and $A$. muricata, respectively (two-way ANOVA, diff $=+0.2$, adj. $p$-value $\leq 0.001 ;$ Figure 1B)

\section{Ingestion Rates of Picoplankton}

In the control beakers without coral colonies, cell concentrations across all plankton groups remained stable or decreased except for bacteria that increased slightly. Synechococcus and Prochlorococcus were the most abundant organisms in the incubation media at the beginning of the experiment $\left(5.10 \pm 0.3910^{4}\right.$ and $8.37 \pm 0.9010^{4}$ cell $\mathrm{mL}^{-1}$, respectively) compared to other pico- and nanoplankton taxa $(3.10 \pm 0.48$ $10^{3}$ cell $\left.\mathrm{mL}^{-1}\right)$. In the beakers containing coral colonies of $P$. damicornis and $G$. fascicularis, the populations of Prochlorococcus and Synechococcus decreased but not those of picoplankton and bacteria (Supplementary Figure 1). Prey increase in beakers containing A. muricata colonies, thus the calculated ingestion rates were negligible (Supplementary Figure 1). Hence, Figure 1C represents only the ingestion rates of Prochlorococcus and Synechococcus by G. fascicularis and P. damicornis. Prochlorococcus decreased by $72 \%$ in beakers containing $P$. damicornis and was the most significantly ingested prey $\left(3.02 \pm 0.1910^{5}\right.$ cell h$^{-1} \mathrm{~cm}^{-2}$; Mann-Whitney-Wilcoxon

test; $p=0.01$, Table 2). G. fascicularis actively and equally fed on Prochlorococcus and Synechococcus, with no significant differences between the ingestion rates $\left(2.56 \pm 1.5710^{4}\right.$ and $2.70 \pm 1.6610^{4}$ cell $\mathrm{h}^{-1} \mathrm{~cm}^{-2}$; Mann-Whitney-Wilcoxon test; $p$ $=0.9$, Table 2). Synechococcus decreased by 24 and $43 \%$ in beakers containing the coral colonies of $P$. damicornis and G. fascicularis, respectively. The corresponding calculated ingestion rates were $1.14 \pm 0.7910^{4}$ and $2.70 \pm 1.6610^{4}$ cell h$^{-1} \mathrm{~cm}^{-2}$, respectively.

\section{DISCUSSION}

By simultaneously quantifying the DDN assimilation rates in three coral species through heterotrophic nutrition on planktonic diazotrophs and symbiotic $\mathrm{N}_{2}$ fixation, this study allows a quantification of the relative contribution of each of these pathways, as well as the distribution of the DDN between two coral compartments (tissue and symbionts). In both $P$. damicornis and $G$. fascicularis, $\mathrm{N}$ assimilation rates through heterotrophy on planktonic diazotrophs were found to be a thousand times higher than those obtained via symbiotic diazotrophs. The high assimilation rates obtained here for two species, as well as those previously obtained for $S$. pistillata using the same methodology (Benavides et al.,

TABLE 4 | Results of a two-way factorial ANOVA testing the effect of coral species, compartments and DDN assimilation rates on the DDN transfer pathway.

DDN transfer pathway: "symbiotic $\mathrm{N}_{2}$ fixation"

\begin{tabular}{lll}
\hline Source $\quad$ Diff & adj. $p$-value \\
\hline
\end{tabular}

\section{Acropora muricata}

Tissue: Symbiodiniaceae

Galaxea fascicularis

Tissue: Symbiodiniaceae

Pocillopora damicornis

Tissue: Symbiodiniaceae

$<0.001$

$<0.001$

$+0.0003$

$<0.001$

DDN transfer pathway: "heterotrophic nutrition on diazotrophs" Acropora muricata

Tissue: Symbiodiniaceae

Galaxea fascicularis

Tissue: Symbiodiniaceae

Pocillopora damicornis

Tissue: Symbiodiniaceae
$-0.003$

0.99

$+0.1$

$+0.5$
0.014

$<0.001$ 
2016; Meunier et al., 2019), demonstrate for the first time that $\mathrm{N}$ assimilation originating from natural plankton fixing $\mathrm{N}_{2}$ or plankton that developed on diazotrophy, seems to be widespread among scleractinian corals. The present study shows that corals with higher heterotrophic capacities compared to Acropora, are capable of directly consuming plankton that developed on $\mathrm{N}_{2}$ fixation. Although we did not measure the grazing of diazotrophs per se, we can hypothesize that these planktonic organisms are both diazotrophs, that are abundant in the New Caledonian lagoon (Turk-Kubo et al., 2015; Bonnet et al., 2016), but also picoplankton that is well known to benefit from this DDN in the New Caledonian lagoon (Prochlorococcus and Synechococcus cells; Berthelot et al., 2016; Bonnet et al., 2016).

\section{DDN Assimilation From Planktonic Diazotrophs}

Colonies of A. muricata, considered to be mainly autotrophic, assimilated very little $\mathrm{N}$ through planktonic diazotrophs, whereas the two species $G$. fascicularis and $P$. damicornis greatly benefited from this $\mathrm{N}$ source by assimilating, respectively, two or four times more DDN through this pathway, compared to A. muricata. After $8 \mathrm{~h}$ of incubation in the dark, in $G$. fascicularis and P. damicornis, the totality of the assimilated DDN through planktonic diazotroph predation occurred within the algal symbionts compartment. DDN assimilation rates from planktonic diazotrophy measured in G. fascicularis $\left(0.11 \pm 0.05 \mu \mathrm{g} \mathrm{N} \mathrm{cm}^{-2} \mathrm{~h}^{-1}\right)$ and $P$. damicornis $(0.517 \pm 0.07 \mu \mathrm{g}$ $\mathrm{N} \mathrm{cm}^{-2} \mathrm{~h}^{-1}$ ) symbionts are in the same range as those previously measured using the same methodology within S. pistillata after $4 \mathrm{~h}$ of incubation also in the dark $(0.76 \pm 0.15 \mu \mathrm{g} \mathrm{N}$ $\mathrm{cm}^{-2} \mathrm{~h}^{-1}$ ) (Benavides et al., 2016). DDN assimilation rates in $P$. damicornis (belonging to the same family, i.e., Pocilloporidae, as $S$. pistillata) after $8 \mathrm{~h}$ of incubation are, however, slightly lower than those of S. pistillata. This suggests that either: (i) S. pistillata colonies exploit more planktonic diazotrophs as a source of $\mathrm{N}$; (ii) a longer incubation ( $8 \mathrm{~h}$ instead of $4 \mathrm{~h}$ for S. pistillata) means that more $\mathrm{N}$ was transferred from the symbionts to the other coral compartments; or (iii) the planktonic community used at the time of the experiment (more or less abundant, with varying degree of $\mathrm{N}_{2}$ fixation activity according to the incubation conditions) influence the DDN transfer to the corals. Regardless, the capacity of DDN assimilation through planktonic diazotrophs in corals from Pocilloporidae family ( $P$. damicornis and S. pistillata) are twice the one of G. fascicularis.

\section{DDN Contribution to Coral Nitrogen Daily Needs}

$\mathrm{N}$ budgets within the coral holobiont remained so far poorly resolved (sensu Fiore et al., 2010; Pernice et al., 2012; Rädecker et al., 2015). Our results indicate for the first time that $G$. fascicularis and $P$. damicornis fulfilled a large part of their $\mathrm{N}$ requirements through heterotrophic feeding on planktonic diazotrophs or plankton which has benefited from diazotrophy. For example, in colonies of S. pistillata, the dissolved inorganic $\mathrm{N}$ uptake rates $\left(\mathrm{NH}_{4}{ }^{+}\right.$and $\mathrm{NO}_{3}{ }^{-}$at in situ concentrations) are at least $2 \mathrm{ng} \mathrm{N} \mathrm{cm}{ }^{-2} \mathrm{~h}^{-1}$ (Grover et al., 2002, 2003). For the plankton density tested, we estimate that the amount of $\mathrm{N}$ coming from planktonic diazotrophy for G. fascicularis and $P$. damicornis (2.51 and $3.44 \mathrm{ng} \mathrm{N} \mathrm{cm}^{-2} \mathrm{~h}^{-1}$, respectively) would therefore be almost equivalent to the $\mathrm{N}$ contribution through inorganic $\mathrm{N}$ uptake.

\section{Picoplankton Ingestion Rates}

Consistent with ${ }^{15} \mathrm{~N}$ data, the higher heterotrophy degree of $P$. damicornis and G. fascicularis is confirmed by the plankton consumption rates. While no ingestion was observed for A. muricata, both G. fascicularis and P. damicornis showed uptake rates ranging from 0.06 to $3.010^{5}$ cell h$^{-1} \mathrm{~cm}^{-2}$. Both species did not ingest bacteria or picoeukaryotes but consumed significant numbers of picocyanobacteria: Synechococcus sp. and Prochlorococcus sp. Our study, focusing only on picoplankton grazing is difficult to compare with previous work interested in pico-nanoplankton as a whole, but ingestion rates of Prochlorococcus and Synechococcus measured here in $P$. damicornis and G. fascicularis are well within the range of cyanobacteria concentrations ingested by $S$. pistillata, G. fascicularis, Montipora digitata, and Porites lutea (Houlbrèque et al., 2004; Tremblay et al., 2012; Sangmanee et al., 2020) in dark conditions also. According to Table 1, Prochlorococcus and Synechococcus ingestion supplied $P$. damicornis with $3.12 \mathrm{ng} \mathrm{N}$ $\mathrm{cm}^{-2} \mathrm{~h}^{-1}$, which is 4 times higher than for G. fascicularis (0.78 ng $\mathrm{N} \mathrm{cm}^{-2} \mathrm{~h}^{-1}$ ). While for P. damicornis, Prochlorococcus was quantitatively the major prey ingested, as already demonstrated in previous studies for S. pistillata (Benavides et al., 2016; Meunier et al., 2019), G. fascicularis consumed both Prochlorococcus and Synechococcus. McNally et al. (2017) had been the first to highlight a selective grazing on specific picoplankton taxa (Synechococcus) by Porites astreoides. These observed differences in coral species diet highlight that corals may have selective prey acquisition strategies. Sizes of Synechococcus and Prochlorococcus being comparable, the mechanisms at the origin of this selection remains to be elucidated.

\section{Estimating the DDN Assimilation Through Symbiotic Diazotrophs Activity}

$\mathrm{N}$ provision via endosymbiotic diazotrophs is negligible compared to that obtained via planktonic diazotrophy, with a factor of $\sim 1,000$ between both pathways for $P$. damicornis and $G$. fascicularis, and almost no symbiotic $\mathrm{N}_{2}$ fixation for A. muricata. These low rates (from $1.76 \pm 0.9010^{-5} \mu \mathrm{g} \mathrm{N}$ $\mathrm{cm}^{-2} \mathrm{~h}^{-1}$ to $3.16 \pm 0.2110^{-4} \mu \mathrm{g} \mathrm{N} \mathrm{cm}{ }^{-2} \mathrm{~h}^{-1}$ ) are in line with those previously measured in other species (Cardini et al., 2015; Bednarz et al., 2017; Meunier et al., 2019). Using an adapted acetylene $\left(\mathrm{C}_{2} \mathrm{H}_{4}\right)$ reduction technique, Cardini et al. (2015) already measured low symbiotic $\mathrm{N}_{2}$ fixation in Acropora sp. (from $3.5710^{-4} \mu \mathrm{g} \mathrm{N} \mathrm{cm}{ }^{-2} \mathrm{~h}^{-1}$ in winter season to 1.17 $10^{-2} \mu \mathrm{g} \mathrm{N} \mathrm{cm}{ }^{-2} \mathrm{~h}^{-1}$ in summer season). Very low rates have been also obtained for $S$. pistillata using the dissolved ${ }^{15} \mathrm{~N}_{2}$ isotopic labeling method after $12 \mathrm{~h}\left(0.31 \pm 0.7710^{-5}\right.$ ng $\mathrm{N} \mathrm{cm}^{-2} \mathrm{~h}^{-1}$ and $0.12 \pm 0.14 \mathrm{ng} \mathrm{cm}^{-2} \mathrm{~h}^{-1}$ ) (Meunier et al., 2019) and after $72 \mathrm{~h}\left(0.97 \pm 0.14 \mathrm{ng} \mathrm{N} \mathrm{cm}{ }^{-2} \mathrm{~h}^{-1}\right.$ and $0.39 \pm 0.08 \mathrm{ng} \mathrm{N} \mathrm{cm}{ }^{-2} \mathrm{~h}^{-1}$ ) (Bednarz et al., 2017) in coral 


\section{A Symbiotic $\mathrm{N}_{2}$ fixation}
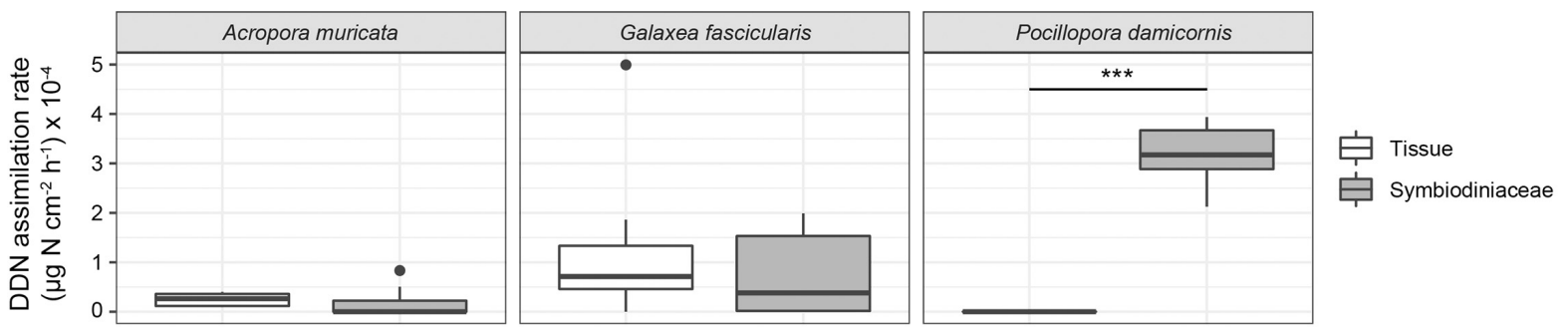

\section{B Heterotrophic nutrition on diazotrophs}
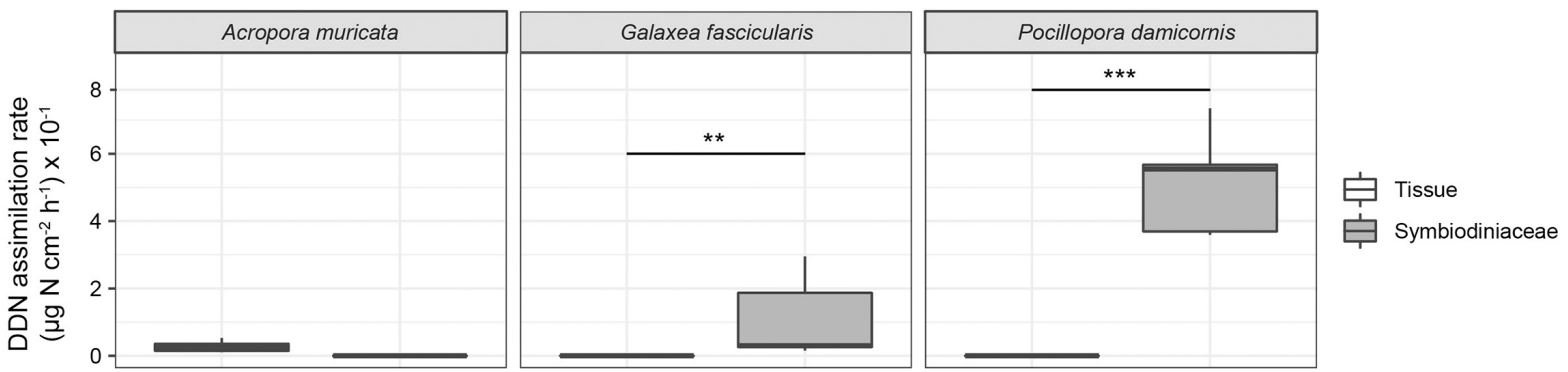

\section{Ingestion rates on picoplankton}
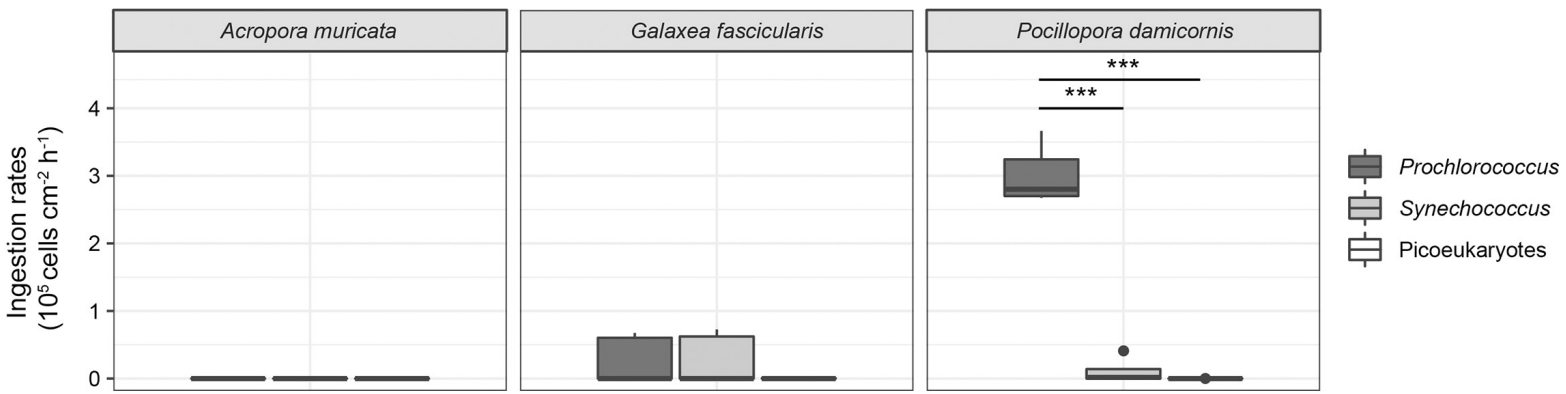

FIGURE 1 | (A) DDN assimilation rates $\left(\mu \mathrm{g} \mathrm{N} \mathrm{cm}{ }^{-2} \mathrm{~h}^{-1}\right)$ into coral tissue and Symbiodiniaceae fraction of $A$. muricata $(N=10)$, G. fascicularis $(N=10$ and 8 for tissue and symbiont, respectively) and $P$. damicornis $(N=10)$ after $8 \mathrm{~h}$ of exposure to ${ }^{15} \mathrm{~N}_{2}$-enriched seawater. Horizontal line in each boxplot indicates the median and black dots represent the outlier sample. The asterisk indicates statistically significant differences (two-way ANOVA, $\left.{ }^{* \star *} p<0.001\right)$. (B) DDN assimilation rates ( $\mu \mathrm{g}$ $\mathrm{N} \mathrm{cm}^{-2} \mathrm{~h}^{-1}$ ) into coral tissue and Symbiodiniaceae fraction of $P$. damicornis, A. muricata and $G$. fascicularis ( $N=5$ for each species) after $8 \mathrm{~h}$ of exposure to ${ }^{15} \mathrm{~N}_{2}$-enriched natural plankton assemblage ( $N=5$ for each species). Horizontal line in each boxplot indicates the median and black dots represent the outlier sample. The asterisk indicates statistically significant differences (two-way ANOVA, $\left.{ }^{\star \star \star} p<0.001,{ }^{\star \star} p<0.01\right)$. (C) Ingestion rates (cell $\mathrm{cm}^{-2} \mathrm{~h}^{-1}$ ) of Prochlorococcus, Synechococcus and picoeukaryotes in A. muricata, G. fascicularis and P. damicornis colonies collected (mean $\pm \mathrm{SE} ; N=5$ ) after $8 \mathrm{~h}$ incubations. Horizontal line in each boxplot indicates the median and black dots represent the outlier samples (Mann-Whitney-Wilcoxon test, ${ }^{\star \star \star} p<0.001$ ).

tissue and algal symbionts, respectively. Even if we used the same technique as Bednarz et al. (2017), different ${ }^{15} \mathrm{~N}_{2}$ enrichments of enriched seawater ( 10 atom\% vs. 30 atom\% in our study) and different incubation times may have affected both the diazotrophic activity and the transfer of DDN into the different coral compartments, justifying the small differences observed between both studies. Although the assimilation rates through symbiotic $\mathrm{N}_{2}$ fixation measured in our study are low, they are higher in the predominantly heterotrophic corals, G. fascicularis (Wijgerde et al., 2011; Conti-Jerpe et al., 2020) and P. damicornis (Lewis and Price, 1975; Sebens et al., 1996; Lyndby et al., 2020), compared to the predominantly autotrophic A. muricata (Conti-Jerpe et al., 2020).
These conclusions are the opposite of those outlined by Pogoreutz et al. (2017b), showing higher symbiotic $\mathrm{N}_{2}$ fixation rates in autotrophic corals than in the heterotrophic ones. However Pogoreutz et al. (2017b) considered P. verrucosa and S. pistillata as autotrophic species while corals from Pocilloporidae family are considered as heterotroph in all studies on coral nutrition, showing in particular a group I feeding strategy (feeding by tentacle capture, Lewis and Price, 1975; Ferrier-Pagès et al., 2003; Houlbrèque et al., 2003, 2004, 2015; Houlbreque, 2004; Lyndby et al., 2020). Results of Pogoreutz et al. (2017b) showed that physiological differences in symbiotic $\mathrm{N}_{2}$ fixation rates among coral species tested align with relative nifH gene copy. So we can hypothesize that more than the functional 
group (autotrophic vs. heterotrophic), it is the abundance and the diazotrophic community associated with each species that seems to influence $\mathrm{N}$ uptake by symbiotic $\mathrm{N}_{2}$ fixation. A. muricata and $P$. damicornis host contrasted communities in the Great Barrier Reef (GBR) (Lema et al., 2012), which might harbor different diazotrophic activity. Thus in our study, differences in the diazotroph community associated with those two species, may explain the observed differences in DDN assimilation via symbiotic $\mathrm{N}_{2}$ fixation.

It should be noted that in the present study, $\mathrm{N}_{2}$ fixation rates by symbiotic diazotrophs were obtained at night, and are therefore maybe slightly lower than rates measured during the day. Bednarz et al. (2017, 2018), as well as Tilstra et al. (2019), found that the ecological dependence of corals on diazotrophy might depend on depth, and so on light availability, with a decrease in relative nifH gene copy numbers with increasing depth. This may be linked to reduce photosynthate translocation by Symbiodiniaceae to the coral host, thus decreasing the fueling of the energy-expensive activity of coral-associated diazotrophs (Pogoreutz et al., 2017a). However, no study until now has measured day/night differences in $\mathrm{N}_{2}$ fixation in corals. Like the rates measured during the day by Cardini et al. (2015), or during day/night cycles by Bednarz et al. (2017), $\mathrm{N}_{2}$ fixation rates by symbiotic diazotrophs in our three tested species remain low and very negligible compared to what is contributed by diazotrophic plankton. P. damicornis colonies preferentially accumulate $\mathrm{N}$ in their symbionts than in their tissue, confirming that symbiotic diazotrophs have a close relationship with algal symbionts which rapidly benefit from the fixed DDN (Lesser et al., 2007; Olson et al., 2009; Pogoreutz et al., 2017b). Unlike P. damicornis, in G. fascicularis, a significant proportion of DDN coming from symbiotic diazotrophs is also found in the tissue compartment.

\section{CONCLUSION}

The present study investigated the patterns of DDN acquisition in three different coral species and allowed us, among other things, to identify whether these patterns changed according to their dependence on heterotrophy. $P$. damicornis and $G$. fascicularis appear to be highly efficient at capturing plankton (either diazotrophs and/or picoplankton that developed on diazotrophy), while A. muricata does not rely on these food resources to meet its $\mathrm{N}$ and energy needs. As climate change destabilizes symbiosis, thus blocking the main source of energy and nutrients, the heterotrophic ability of corals as an alternative nutrient resource plays an essential role in their survival (e.g., Sebens et al., 1996; Grottoli et al., 2006; Anthony et al., 2009; Tremblay et al., 2016; Conti-Jerpe et al., 2020; Fernandes de Barros Marangoni et al., 2020; Rädecker et al., 2021). From our results, we can expect that coral species such as $P$. damicornis and $G$. fascicularis, which are able to meet their $\mathrm{N}$ equally by planktonic diazotrophy and dissolved inorganic sources, will be able to maintain their energy reserves to cope with climate change. On the opposite, corals that are mainly autotrophic such as A. muricata may not adapt and survive, as heat stress events will become more frequent and intense. A previous study (Meunier et al., 2019) has demonstrated that bleached colonies of Stylophora pistillata were able to increase their feeding rate precisely on these planktonic diazotrophs but also on Synechococcus cyanobacteria, whose cells are rich in N (Bertilsson et al., 2003; Jacquet et al., 2006). So our study reveals that coral species that highly depend on heterotrophy could, in the event of bleaching, rely not only on the supply of nutrients and energy from meso-macroplankton but also on a major supply of $\mathrm{N}$ by planktonic diazotrophs and picoplankton. Taking advantage of the consumption of planktonic diazotrophs or picoplankton that have developed on diazotrophy could be one of the main strategies for coral recovery facing bleaching, as both the activity and geographical distribution of diazotrophs will likely increase with future rising sea surface temperature (Breitbarth et al., 2007; Levitan et al., 2007; Hutchins et al., 2017).

\section{DATA AVAILABILITY STATEMENT}

The original contributions presented in the study are included in the article/ Supplementary Material, further inquiries can be directed to the corresponding author/s.

\section{AUTHOR CONTRIBUTIONS}

$\mathrm{VM}, \mathrm{FH}$, and $\mathrm{SB}$ conceived the ideas and designed the methodology. VM and FH performed the experiments and led the writing of the manuscript. OG and CL carried out some of the laboratory analyses. VM and AR performed the statistical analyses. All authors contributed critically to the drafts and gave the final approval for publication.

\section{FUNDING}

VM was the beneficiary of a Ph.D. grant from LabEx-Corail (MACADAM project). This work was also funded by the EC2CO/BIOEFECT program (TOUCAN project).

\section{ACKNOWLEDGMENTS}

We thank the Race for Water Foundation for allowing us to carry out these experiments on board their vessel and all the crew members for their help. We are especially grateful to A. Tilstra and L. Montilla for critical reading and valuable comments on this manuscript.

\section{SUPPLEMENTARY MATERIAL}

The Supplementary Material for this article can be found online at: https://www.frontiersin.org/articles/10.3389/fmars.2021. 692248/full\#supplementary-material

Supplementary Figure 1 | Abundances (cell mL ${ }^{-1}$ ) of Prochlorococcus, Synechococcus and picoeukaryotes in the beakers containing (A) A. muricata colonies, (B) G. fascicularis colonies and (C) P. damicornis colonies before $\left(T_{0}\right)$ and after $\left(T_{f}\right)$ the $8 \mathrm{~h}$ incubations. 


\section{REFERENCES}

Anthony, K. R. N., Hoogenboom, M. O., Maynard, J. A., Grottoli, A. G., and Middlebrook, R. (2009). Energetics approach to predicting mortality risk from environmental stress: a case study of coral bleaching. Funct. Ecol. 23, 539-550. doi: 10.1111/j.1365-2435.2008.01531.x

Bednarz, V. N., Grover, R., Maguer, J.-F., Fine, M., and Ferrier-Pagès, C. (2017). The assimilation of diazotroph-derived nitrogen by scleractinian corals. MBio 8:e02058-16.

Bednarz, V. N., Naumann, M. S., Cardini, U., Van Hoytema, N., Rix, L., AlRshaidat, M. M. D., et al. (2018). Contrasting seasonal responses in dinitrogen fixation between shallow and deep-water colonies of the model coral Stylophora pistillata in the northern Red Sea. PLoS One 13:e0199022. doi: 10.1371/journal. pone.0199022

Bednarz, V. N., van de Water, J. A. J. M., Rabouille, S., Maguer, J. F., Grover, R., and Ferrier-Pagès, C. (2019). Diazotrophic community and associated dinitrogen fixation within the temperate coral Oculina patagonica. Environ. Microbiol. 21, 480-495. doi: 10.1111/1462-2920.14480

Benavides, M., Bednarz, V. N., and Ferrier-Pagès, C. (2017). Diazotrophs: overlooked key players within the coral symbiosis and tropical reef ecosystems? Front. Mar. Sci. 4:10. doi: 10.3389/fmars.2017.00010

Benavides, M., Houlbreque, F., Camps, M., Lorrain, A., Grosso, O., and Bonnet, S. (2016). Diazotrophs: a non-negligible source of nitrogen for the tropical coral Stylophora pistillata. J. Exp. Biol. 219, 2608-2612. doi: 10.1242/jeb. 139451

Berthelot, H., Bonnet, S., Grosso, O., Cornet, V., and Barani, A. (2016). Transfer of diazotroph-derived nitrogen towards non-diazotrophic planktonic communities: a comparative study between Trichodesmium erythraeum Crocosphaera watsonii and Cyanothece sp. Biogeosciences 13, 4005-4021. doi: 10.5194/bg-13-4005-2016

Bertilsson, S., Berglund, O., Karl, D. M., and Chisholm, S. W. (2003). Elemental composition of marine Prochlorococcus and Synechococcus: implications for the ecological stoichiometry of the sea. Limnol. Oceanogr. 48, 1721-1731. doi: 10.4319/lo.2003.48.5.1721

Bonnet, S., Berthelot, H., Turk-Kubo, K., Fawcett, S., Rahav, E., L'Helguen, S., et al. (2016). Dynamics of N2 fixation and fate of diazotroph-derived nitrogen in a low-nutrient, low-chlorophyll ecosystem: results from the VAHINE mesocosm experiment (New Caledonia). Biogeosciences 13, 2653-2673. doi: 10.5194/bg13-2653-2016

Bourne, D. G., Morrow, K. M., and Webster, N. S. (2016). Insights into the coral microbiome: underpinning the health and resilience of reef ecosystems. Annu. Rev. Microbiol. 70, 317-340. doi: 10.1146/annurev-micro-102215095440

Breitbarth, E., Oschlies, A., and LaRoche, J. (2007). Physiological constraints on the global distribution of Trichodesmium - effect of temperature on diazotrophy. Biogeosciences 4, 53-61. doi: 10.5194/bg-4-53-2007

Buitenhuis, E. T., Li, W. K. W., Vaulot, D., Lomas, M. W., Landry, M. R., Partensky, F., et al. (2012). Picophytoplankton biomass dis- tribution in the global ocean. Earth Syst. Sci. Data 4, 37-46. doi: 10.5194/essd-4-37-2012

Cardini, U., Bednarz, V. N., Naumann, M. S., van Hoytema, N., Rix, L., Foster, R. A., et al. (2015). Functional significance of dinitrogen fixation in sustaining coral productivity under oligotrophic conditions. Proc. R. Soc. B Biol. Sci. 282:20152257. doi: 10.1098/rspb.2015.2257

Conti-Jerpe, I. E., Thompson, P. D., Wong, C. W. M., Oliveira, N. L., Duprey, N. N., Moynihan, M. A., et al. (2020). Trophic strategy and bleaching resistance in reef-building corals. Sci. Adv. 6:eaaz5443. doi: 10.1126/sciadv. aaz5443

De Goeij, J. M., Van Oevelen, D., Vermeij, M. J. A., Osinga, R., Middelburg, J. J., De Goeij, A. F. P. M., et al. (2013). Surviving in a marine desert: the sponge loop retains resources within coral reefs. Science 342, 108-110. doi: 10.1126/science. 1241981

Falkowski, P. G., Dubinsky, Z., Muscatine, L., and McCloskey, L. (1993). Population control in symbiotic corals - Ammonium ions and organic materials maintain the density of zooxanthellae. Bioscience 43, 606-611. doi: 10.2307/ 1312147

Fernandes de Barros Marangoni, L., Ferrier-Pagès, C., Rottier, C., Bianchini, A., and Grover, R. (2020). Unravelling the different causes of nitrate and ammonium effects on coral bleaching. Sci. Rep. 10:11975. doi: 10.1038/s41598-02068916-0

Ferrier-Pagès, C., Witting, J., Tambutté, E., and Sebens, K. P. (2003). Effect of natural zooplankton feeding on the tissue and skeletal growth of the scleractinian coral Stylophora pistillata. Coral Reefs 22, 229-240. doi: 10.1007/ s00338-003-0312-7

Fiore, C. L., Jarett, J. K., Olson, N. D., and Lesser, M. P. (2010). Nitrogen fixation and nitrogen transformations in marine symbioses. Trends Microbiol. 18, 455463. doi: 10.1016/j.tim.2010.07.001

Goldberg, W. M. (2018). Coral food, feeding, nutrition, and secretion: a review. Results Probl. Cell Differ. 65, 377-421. doi: 10.1007/978-3-319-92 486-1_18

Goreau, T. F., Goreau, N. I., and Yonge, C. M. (1971). Reef corals: autotrophs or heterotrophs? Biol. Bull. 141, 247-260. doi: 10.2307/1540115

Grokopf, T., Mohr, W., Baustian, T., Schunck, H., Gill, D., Kuypers, M. M. M., et al. (2012). Doubling of marine dinitrogen-fixation rates based on direct measurements. Nature 488, 361-364. doi: 10.1038/nature 11338

Grottoli, A. G., Rodrigues, L. J., and Palardy, J. E. (2006). Heterotrophic plasticity and resilience in bleached corals. Nature 440, 1186-1189. doi: 10.1038/ nature 04565

Grover, R., Maguer, J. F., Allemand, D., and Ferrier-Pagès, C. (2003). Nitrate uptake in the scleractinian coral Stylophora pistillata. Limnol. Oceanogr. 48, 2266-2274. doi: 10.4319/lo.2003.48.6.2266

Grover, R., Maguer, J. F., Reynaud-Vaganay, S., and Ferrier-Pagès, C. (2002). Uptake of ammonium by the scleractinian coral Stylophora pistillata: effect of feeding, light, and ammonium concentrations. Limnol. Oceanogr. 47, 782-790. doi: $10.4319 /$ lo.2002.47.3.0782

Houlbreque, F. (2004). Interactions between zooplankton feeding, photosynthesis and skeletal growth in the scleractinian coral Stylophora pistillata. J. Exp. Biol. 207, 1461-1469. doi: 10.1242/jeb.00911

Houlbrèque, F., and Ferrier-Pagès, C. (2009). Heterotrophy in tropical scleractinian corals. Biol. Rev. 84, 1-17.

Houlbrèque, F., Reynaud, S., Godinot, C., Oberhänsli, F., Rodolfo-Metalpa, R., and Ferrier-Pagés, C. (2015). Ocean acidification reduces feeding rates in the scleractinian coral Stylophora pistillata. Limnol. Oceanogr. 60, 89-99. doi: 10. 1002/lno.10003

Houlbrèque, F., Tambutté, E., and Ferrier-Pagès, C. (2003). Effect of zooplankton availability on the rates of photosynthesis, and tissue and skeletal growth in the scleractinian coral Stylophora pistillata. J. Exp. Mar. Bio. Ecol. 296, 145-166. doi: 10.1016/S0022-0981(03)00259-4

Houlbrèque, F., Tambutté, E., Richard, C., and Ferrier-pagès, C. (2004). Importance of a micro-diet for scleractinian corals. Mar. Ecol. Prog. Ser. 282, 151-160.

Howarth, R. W. (1988). Nutrient limitation of net primary production in marine ecosystems. Annu. Rev. Ecol. Syst. 19, 89-110.

Hutchins, D. A., Fu, F., Walworth, N. G., Lee, M. D., Saito, M. A., and Webb, E. A. (2017). Comment on "The complex effects of ocean acidification on the prominent N2-fixing cyanobacterium Trichodesmium.”. Science 357, 527-531. doi: 10.1126/science.aao0067

Jacquet, S., Delesalle, B., Torréton, J. P., and Blanchot, J. (2006). Response of phytoplankton communities to increased anthropogenic influences (southwestern lagoon, New Caledonia). Mar. Ecol. Prog. Ser. 320, 65-78. doi: 10.3354/meps320065

Kana, T. M., Darkangelo, C., Hunt, M. D., Oldham, J. B., Bennett, G. E., and Cornwell, J. C. (1994). Membrane inlet mass spectrometer for rapid highprecision determination of $\mathrm{N} 2, \mathrm{O} 2$, and ar in environmental water samples. Anal. Chem. 66, 4166-4170. doi: 10.1021/ac00095a009

LaJeunesse, T. C., Parkinson, J. E., Gabrielson, P. W., Jeong, H. J., Reimer, J. D., Voolstra, C. R., et al. (2018). Systematic revision of symbiodiniaceae highlights the antiquity and diversity of coral endosymbionts. Curr. Biol. 28, 2570-2580.e6. doi: 10.1016/j.cub.2018.07.008

Lema, K. A., Willis, B. L., and Bourneb, D. G. (2012). Corals form characteristic associations with symbiotic nitrogen-fixing bacteria. Appl. Environ. Microbiol. 78, 3136-3144. doi: 10.1128/AEM.07800-11

Lesser, M. P., Falcón, L. I., Rodríguez-Román, A., Enríquez, S., HoeghGuldberg, O., and Iglesias-Prieto, R. (2007). Nitrogen fixation by symbiotic cyanobacteria provides a source of nitrogen for the scleractinian coral 
Montastraea cavernosa. Mar. Ecol. Prog. Ser. 346, 143-152. doi: 10.3354/meps 07008

Lesser, M. P., Morrow, K. M., and Pankey, M. S. (2019). N2 fixation, and the relative contribution of fixed N, in corals from Curaçao and Hawaii. Coral Reefs 38, 1145-1158. doi: 10.1007/s00338-019-01863-Z

Lesser, M. P., Morrow, K. M., Pankey, S. M., and Noonan, S. H. C. (2018). Diazotroph diversity and nitrogen fixation in the coral Stylophora pistillata from the Great Barrier Reef. ISME J. 12, 813-824. doi: 10.1038/s41396-0170008-6

Levitan, O., Rosenberg, G., Setlik, I., Setlikova, E., Grigel, J., Klepetar, J., et al. (2007). Elevated CO2 enhances nitrogen fixation and growth in the marine cyanobacterium Trichodesmium. Glob. Chang. Biol. 13, 531-538. doi: 10.1111/ j.1365-2486.2006.01314.x

Lewis, J. B., and Price, W. S. (1975). Feeding mechanisms and feeding strategies of Atlantic reef corals. J. Zool. 176, 527-544. doi: 10.1111/j.1469-7998.1975. tb03219.x

Lyndby, N., Holm, J., Wangpraseurt, D., Grover, R., Rottier, C., Kühl, M., et al. (2020). Effect of temperature and feeding on carbon budgets and $\mathrm{O} 2$ dynamics in Pocillopora damicornis. Mar. Ecol. Prog. Ser. 652, 49-62. doi: 10.3354/ meps 13474

Marie, D., Brussaard, C. P. D., Thyrhaug, R., Bratbak, G., and Vaulot, D. (1999). Enumeration of marine viruses in culture and natural samples by flow cytometry. Appl. Environ. Microbiol. 65, 45-52. doi: 10.1128/aem.65.1.45-52. 1999

Marie, D., Partensky, F., Jacquet, S., and Vaulot, D. (1997). Enumeration and cell cycle analysis of natural populations of marine picoplankton by flow cytometry using the nucleic acid stain SYBR Green I. Appl. Environ. Microbiol. 63, 186-193. doi: 10.1128/aem.63.1.186-193. 1997

McNally, S. P., Parsons, R. J., Santoro, A. E., and Apprill, A. (2017). Multifaceted impacts of the stony coral Porites astreoides on picoplankton abundance and community composition. Limnol. Oceanogr. 62, 217-234. doi: 10.1002/lno. 10389

Messer, L. F., Brown, M. V., Furnas, M. J., Carney, R. L., McKinnon, A. D., and Seymour, J. R. (2017). Diversity and activity of diazotrophs in great barrier reef surface waters. Front. Microbiol. 8:967. doi: 10.3389/fmicb.2017. 00967

Meunier, V., Bonnet, S., Pernice, M., Benavides, M., Lorrain, A., Grosso, O., et al. (2019). Bleaching forces coral's heterotrophy on diazotrophs and Synechococcus. ISME J. 13, 2882-2886. doi: 10.1038/s41396-019-0 456-2

Mills, M. M., and Sebens, K. P. (2004). Ingestion and assimilation of nitrogen from benthic sediments by three species of coral. Mar. Biol. 145, 1097-1106. doi: 10.1007/s00227-004-1398-3

Mills, M. M., Lipschultz, F., and Sebens, K. P. (2004). Particulate matter ingestion and associated nitrogen uptake by four species of scleractinian corals. Coral Reefs 23, 311-323. doi: 10.1007/s00338-004-0380-3

Mohr, W., Großkopf, T., Wallace, D. W. R., and LaRoche, J. (2010). Methodological underestimation of oceanic nitrogen fixation rates. PLoS One 5:e12583. doi: 10.1371/journal.pone.0012583

Muscatine, L. (1990). "The role of symbiotic algae in carbon and energy flux in reef corals," in Ecosystems of the World. Coral Reefs, ed. Z. Dubinsky (Elsevier: Amsterdam), 75-87.

Muscatine, L., and Porter, J. W. (1977). Reef corals: mutualistic symbioses adapted to nutrient-poor environments. Bioscience 27, 454-460. doi: 10.2307/12 97526

Naumann, M. S., Richter, C., El-Zibdah, M., and Wild, C. (2009). Coral mucus as an efficient trap for picoplanktonic cyanobacteria: implications for pelagicbenthic coupling in the reef ecosystem. Mar. Ecol. Prog. Ser. 385, 65-76. doi: 10.3354/meps08073

Olson, N. D., Ainsworth, T. D., Gates, R. D., and Takabayashi, M. (2009). Diazotrophic bacteria associated with Hawaiian Montipora corals: diversity and abundance in correlation with symbiotic dinoflagellates. J. Exp. Mar. Biol. Ecol. 371, 140-146. doi: 10.1016/j.jembe.2009. 01.012

Pernice, M., Meibom, A., Van Den Heuvel, A., Kopp, C., Domart-Coulon, I., Hoegh-Guldberg, O., et al. (2012). A single-cell view of ammonium assimilation in coral-dinoflagellate symbiosis. ISME J. 6, 1314-1324. doi: 10.1038/ismej. 2011.196

Pogoreutz, C., Rädecker, N., Cárdenas, A., Gärdes, A., Voolstra, C. R., and Wild, C. (2017a). Sugar enrichment provides evidence for a role of nitrogen fixation in coral bleaching. Glob. Chang. Biol. 23, 3838-3848. doi: 10.1111/gcb.13695

Pogoreutz, C., Rädecker, N., Cárdenas, A., Gärdes, A., Wild, C., and Voolstra, C. R. (2017b). Nitrogen fixation aligns with nifH abundance and expression in two coral trophic functional groups. Front. Microbiol. 8:1187. doi: 10.3389/fmicb. 2017.01187

Rädecker, N., Pogoreutz, C., Gegner, H. M., Cárdenas, A., and Roth, F. (2021). Heat stress destabilizes symbiotic nutrient cycling in corals. Proc. Natl. Acad. Sci. U.S.A. 118:e2022653118. doi: 10.1073/pnas.2022653118

Rädecker, N., Pogoreutz, C., Voolstra, C. R., Wiedenmann, J., and Wild, C. (2015). Nitrogen cycling in corals: the key to understanding holobiont functioning? Trends Microbiol. 23, 490-497. doi: 10.1016/j.tim.2015.03.008

Redfield, A. C. (1958). The biological control of chemical factors in the environment. Am. Sci. 46, 205-221.

Ribes, M., Coma, R., and Gili, J. M. (1998). Heterotrophic feeding by gorgonian corals with symbiotic zooxanthella. Limnol. Oceanogr. 43, 1170-1179. doi: 10. 4319/lo.1998.43.6.1170

Rodolfo-Metalpa, R., Martin, S., Ferrier-Pagès, C., and Gattuso, J.-P. (2010). Response of the temperate coral Cladocora caespitosa to mid- and long-term exposure to pCo2 and temperature levels projected for the year $2100 \mathrm{AD}$. Biogeosciences 7, 289-300.

Rohwer, F., Seguritan, V., Azam, F., and Knowlton, N. (2002). Diversity and distribution of coral-associated bacteria. Mar. Ecol. Prog. Ser. 243, 1-10. doi: $10.3354 /$ meps 243001

Rosenberg, E., Koren, O., Reshef, L., Efrony, R., and Zilber-Rosenberg, I. (2007). The role of microorganisms in coral health, disease and evolution. Nat. Rev. Microbiol. 5, 355-362. doi: 10.1038/nrmicro1635

Sangmanee, K., Casareto, B. E., Nguyen, T. D., Sangsawang, L., Toyoda, K., Suzuki, T., et al. (2020). Influence of thermal stress and bleaching on heterotrophic feeding of two scleractinian corals on pico-nanoplankton. Mar. Pollut. Bull. 158:111405. doi: 10.1016/j.marpolbul.2020.111405

Santos, H. F., Carmo, F. L., Duarte, G., Dini-Andreote, F., Castro, C. B., Rosado, A. S., et al. (2014). Climate change affects key nitrogen-fixing bacterial populations on coral reefs. ISME J. 8, 2272-2279. doi: 10.1038/ismej.2014.70

Saulia, E., Benavides, M., Henke, B., Turk-Kubo, K., Cooperguard, H., Grosso, O., et al. (2020). Seasonal shifts in diazotrophs players: patterns observed over a two-year time series in the new caledonian lagoon (Western Tropical South Pacific Ocean). Front. Mar. Sci. 7:581755. doi: 10.3389/fmars.2020.581755

Sebens, K. P., Vandersall, K. S., Savina, L. A., and Graham, K. R. (1996). Zooplankton capture by two scleractinian corals,Madracis mirabilis and Montastrea cavernosa, in a field enclosure. Mar. Biol. 127, 303-317. doi: 10. 1007/BF00942116

Stimson, J., and Kinzie, R. A. (1991). The temporal pattern and rate of release of zooxanthellae from the reef coral Pocillopora damicornis (Linnaeus) under nitrogen-enrichment and control conditions. J. Exp. Mar. Biol. Ecol. 153, 63-74. doi: 10.1016/S0022-0981(05)80006-1

Tilstra, A., Pogoreutz, C., Rädecker, N., Ziegler, M., Wild, C., and Voolstra, C. R. (2019). Relative diazotroph abundance in symbiotic red sea corals decreases with water depth. Front. Mar. Sci. 6:372. doi: 10.3389/fmars.2019.00372

Tilstra, A., Van Hoytema, N., Cardini, U., Bednarz, V. N., Rix, L., Naumann, M. S., et al. (2018). Effects of water column mixing and stratification on planktonic primary production and dinitrogen fixation on a northernred sea coral reef. Front. Microbiol. 9:2351. doi: 10.3389/fmicb.2018.02351

Toh, T. C., Peh, J. W. K., and Chou, L. M. (2013). Heterotrophy in recruits of the scleractinian coral Pocillopora damicornis. Mar. Freshw. Behav. Physiol. 46, 313-320. doi: 10.1080/10236244.2013.832890

Tremblay, P., Gori, A., Maguer, J. F., Hoogenboom, M., and Ferrier-Pagès, C. (2016). Heterotrophy promotes the re-establishment of photosynthate translocation in a symbiotic coral after heat stress. Sci. Rep. 6:38112. doi: 10. 1038/srep38112

Tremblay, P., Naumann, M. S., Sikorski, S., Grover, R., and Ferrier-Pagès, C. (2012). Experimental assessment of organic carbon fluxes in the scleractinian coral Stylophora pistillata during a thermal and photo stress event. Mar. Ecol. Prog. Ser. 453, 63-77. doi: 10.3354/meps09640 
Turk-Kubo, K. A., Frank, I. E., Hogan, M. E., Desnues, A., Bonnet, S., and Zehr, J. P. (2015). Diazotroph community succession during the VAHINE mesocosms experiment (New Caledonia Lagoon). Biogeosci. 12, 9043-9079. doi: 10.5194/ bgd-12-9043-2015

van Oppen, M. J. H., and Blackall, L. L. (2019). Coral microbiome dynamics, functions and design in a changing world. Nat. Rev. Microbiol. 17, 557-567. doi: 10.1038/s41579-019-0223-4

Wickham, H. (2008). Elegant Graphics for Data Analysis: ggplot2. Berlin: Springer.

Wijgerde, T., Diantari, R., Lewaru, M. W., Verreth, J. A. J., and Osinga, R. (2011). Extracoelenteric zooplankton feeding is a key mechanism of nutrient acquisition for the scleractinian coral Galaxea fascicularis. J. Exp. Biol. 214(Pt. 20), 3351-3357. doi: 10.1242/jeb.0 58354

Wild, C., Huettel, M., Klueter, A., Kremb, S. G., Rasheed, M. Y. M., and Jørgensen, B. B. (2004). Coral mucus functions as an energy carrier and particle trap in the reef ecosystem. Nature 428, 66-70. doi: $10.1038 /$ nature 02344
Conflict of Interest: The authors declare that the research was conducted in the absence of any commercial or financial relationships that could be construed as a potential conflict of interest.

Publisher's Note: All claims expressed in this article are solely those of the authors and do not necessarily represent those of their affiliated organizations, or those of the publisher, the editors and the reviewers. Any product that may be evaluated in this article, or claim that may be made by its manufacturer, is not guaranteed or endorsed by the publisher.

Copyright (C) 2021 Meunier, Bonnet, Benavides, Ravache, Grosso, Lambert and Houlbrèqu. This is an open-access article distributed under the terms of the Creative Commons Attribution License (CC BY). The use, distribution or reproduction in other forums is permitted, provided the original author(s) and the copyright owner(s) are credited and that the original publication in this journal is cited, in accordance with accepted academic practice. No use, distribution or reproduction is permitted which does not comply with these terms. 